


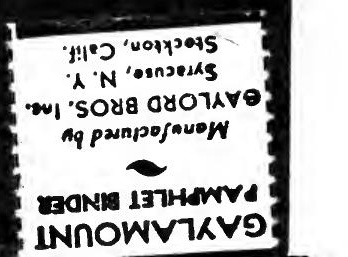




\section{A CRITICAL STUDY OF CURRENT THEORIES OF MORAL EDUCATION}

\section{A DISSERTATION}

SUBMITTED TO THE FACULTY OF THE GRADUATE SCHOOL OF ARTS AND LITERATURE IN CANDIDACY FOR THE DEGREE OF DOCTOR OF PHILOSOPHY (DEPARTMENT OF EDUCATION)

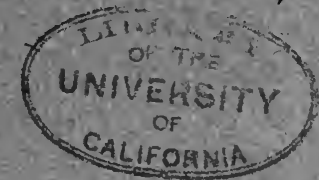

BY

JOSEPH KINMONT HART

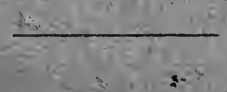

\section{CHICAGO}

THE UNIVERSITY OF CHICAGO PRESS

1910 
Digitized by the Internet Archive in 2007 with funding from Microsoft Corporation 


\section{A CRITICAL STUDY OF CURRENT THEORIES OF MORAL EDUCATION}

\section{A DISSERTATION}

SUBMITTED TO THE FACULTY OF THE GRADUATE SCHOOL OF ARTS AND LITERATURE IN CANDIDACY FOR THE DEGREE OF DOCTOR OF PHILOSOPHY (DEPARTMENT OF EDUCATION)

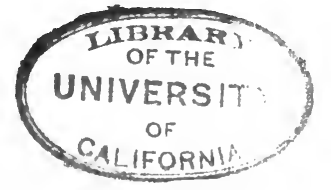

BY

JOSEPH KINMONT ${ }_{\|}^{\text {HART }}$

CHICAGO

THE UNIVERSITY OF CHICAGO PRESS

I 910 
Copyright rgio By

The Universtry of Chicago

Published April rgro

Composed and Printed By

The University of Chicago Press Chicago, Illinois, U.S.A 


\section{PREFACE}

This study was evolved in connection with the writer's work in the departments of philosophy, psychology, and sociology. It is not a report of work done in a laboratory, though laboratories are not unknown to the writer. It is herein implied, if not explicitly stated, that the greatest problem in the educational situation, today, is one which cannot adequately be handled in the mere laboratory. In fact, it cannot be found inside a laboratory. It is the larger problem of the intimate logic of experience, in which concrete educational values are created and assimilated, and the wider problem of the uncertain play of those social forces which alone can give adequate stimulation to the individual's educational activities. Out of these vital situations there may arise, here and there, important problems of detail which can be handled successfully only in a laboratory. But laboratory and "life" must alike contribute to the development of a convincing "logic of experience" which will serve as a more adequate guide in pedagogical practice.

The following writings and materials have helped to mold the point of view underlying this study: in psychology, Angell's Psychology; articles by Dewey, especially on "The Reflex Arc Concept," and "The Theory of Emotions"; Cooley's Human Nature and the Social Order; and particularly some unpublished lectures by Professor G. H. Mead, on "Social Psychology," and "The Logic of the Social Sciences"; in logic, Dewey's Studies in Logical Theory, supplemented by studies in the development of logical theory, with Professor A. W. Moore; Ethics by Dewey and Tufts, with work in the historical evolution of morality and ethics with Professor Tufts, gives the fundamental point of view; and the general educational standpoint is found in unpublished lectures by Professors Dewey, Mead, Angell, Tufts, and Henderson. 



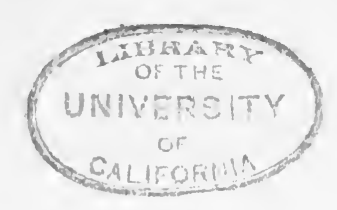

\section{INTRODUCTION}

Present-day awareness of the insufficiency of our educational results, and present-day protests against traditional educational theory and practice have become very specific in form, and are becoming very general in extent.

We are being told by Dr. Edward Everett Hale that our public-school system almost fails in instilling morality, by President Eliot that the intelligence produced is ineffective and not worth the money spent, by Admiral Evans that its product is contemptible, by Fiske that it is useless in business, by Edison that it has no profitable relation to applied science, by A. C. Benson and Sir Frederic Harrison that it is eminently successful in turning out uniformly stupid types, void of originality, by Rabbi Hirsch that it is the biggest failure of modern times.

It is true that much of this sort of criticism is largely rhetorical; but the mass of it, which fills unnumbered pages of periodical literature, and books without end, is not only true as applied to the public-school system, but, to a greater or less degree, of all forms of educational activity. The critical and reconstructive forces of the modern world, which have been producing such profound and beneficent changes in many phases of our world-experience, are but slowly penetrating into the region of educational theory and practice. This is, of course, quite in keeping with the general logic of experience: that which is most intimate in experience yields itself last of all and most unwillingly to the criticisms and reconstructions which the changing order brings.

In spite of this fact, much has already been accomplished in the direction of educational reconstruction. Society as a whole, however, lacks the reconstructive purpose. Reconstruction, too often, connotes mere iconoclastic innovation, lacking seriousness of programme. There is popular distrust of the efficacy of present reconstructive methods. There is a decided unwillingness to permit educational institutions and activities to be thrown into the general current of scientific experimentation. Even educational theory maintains a certain sacredness of character. All this is due, partly to the sacred regard in which "education" is held, especially by the American mind; partly to the naïve distrust of experimental methods. But the values of these new ideals can be determined only by passing

I Johnston, "Social Significance of Various Movements for Industrial Education," Educational Review, Vol. XXXVII, pp. I60-80. 
them through the fierce heats of battles with old ideals in a very real "struggle for existence." In this way, the "new education" is slowly working its way into social consciousness, and becoming a part of social method. And as society becomes more and more self-directive, self-controlled, and self-conscious, the spirit of reconstruction will find itself more and more at home in the region of pedagogical activity, and more profound and far-reaching results will follow, both for the child and for the social whole. For, in this way of education, alone, will come that more intelligent control of the whole process of social growth and reproduction which is, at present, the hope of social theorists. ${ }^{x}$

If we should attempt to sum up all the criticisms of present-day results in education, one word would, perhaps, suffice to cover all points of attack. Almost all criticisms agree that our actual educational results are, in varying degrees, irrelevant to the actual life-conditions of the modern world. They do not effectually function in relating the growing individual to the actual world in which he is to live. Accordingly, all efforts under the direction of the "new education" are employed in the task of securing results that will be relevant to the world in which the developing individual is to live. Some of these efforts are, in themselves, more or less irrelevant to the situation, because they are mechanical and arbitrary in every way, while the present trend of affairs is in the direction of a more vital emphasis upon personality; some of them but repeat, under other forms, traditional errors; but the most vital and promising of these efforts have set themselves some more or less complete phase of the definite task of scientifically considering the whole field of education in its relation to the whole of life, with the hope of working out some more completely organic conception of the process. We shall note some of these attempts later; here it is necessary to make clear the central problem of the educational situation of today.

There is a "new" biology which attempts to state the appearance of specific forms of organisms in terms of the life-conditions which obtain in the production of those forms. This procedure is becoming the generalized method of wide ranges of scientific inquiry. Thus, psychology is attempting to describe the conditions under which the phenomena of mental life appear; logic is interested in the conditions under which we realize our worlds of physical and social relationships; and ethics is giving us the historical and psychological conditions under which the progressive realization of our moral values goes on in concrete experience. Now, in so far as education is anything more than the mere absorption of concrete social habits, or the mere impartation of concrete information, such sciences

I Sumner, Folkways, p. II 8 . 
as psychology, logic, and ethics have been peculiarly efficient in rescuing it from its primitive naïveté. But the persistent problem in educational theory, today, is this: Can education be reconstructed on the basis of the functional aspects of these foundation sciences? Can the creative aspect of experience, as contrasted with the merely cumulative aspect, be made the central factor in the organization of educational activities? Can the process of mental development be substituted for the traditional method of mere impartation of ideas?

There is still a profound difference of opinion at this point. Over against any suggestion of change in the fundamentals of educational practice, the old tradition rises in protest. It is a theoretically impregnable position that (to quote a modern German writer), "Weltanschauung und Unterricht müssen miteinander harmonieren"; but in practice there seems to be a fundamental conflict between the very concept of "Unterricht," and the modern "Weltanschauung." The same writer declares, further: "Wir dürfen auch die alten Bausteine nicht mehr benutzen, wenn wir sehen sie morsch geworden sind." But conservative educational practice replies: "Is it certain that the old foundations are rotten? And, if they are, can these modern 'structureless' sciences give us actual and substantial foundations in their stead? Do they not, rather, destroy all possibility of secure foundation?"

However, since education is a vital phase of the whole of the social process, and not a mere addendum to it, any change in the general social point of view must be reflected, in some measure, in educational theory and practice; and if that changed social point of view should profoundly affect the very heart of the social process and the conception of social method, educational activities must be profoundly affected, likewise: the present unrest is witness of this principle. Compayré has pointed out that "to the changing conceptions in psychology changing conceptions in pedagogy constantly correspond," and that "every ethical system contains within itself the germs of an original and appropriate system of pedagogy." $x$ In another place he speaks of the effects upon pedagogical practice of changing points of view in logical theory.

The issue is, thus, fairly joined between these foundation sciences of psychology, logic, and ethics, and that superstructure of educational theory and practice which is built upon them. These sciences have been profoundly changed in recent years, so much so, indeed, that the older conceptions are no longer dynamically present in our constructive thinking or in our thoughtful activities: how, then, shall education, which rests

x Compayré, Histoire de la pédagogie, p. xi. 
upon them, escape the profound reconstruction which is implicit in this changed foundation?

But the issue is deeper than a mere struggle between points of view in contemporary scientific doctrine. The changed points of view in psychology, logic, and ethics do not make manifest in scientific forms the changed points of view in concrete social processes. It is a social change of method; it has gone far on its theoretical side: the present and the immediate future are waiting to see whether society will be able to carry out in any complete and practical way the educational reconstructions which are demanded by these theoretical considerations, and which are most urgently rooted in the very logic of present-day social conditions.

This study will be devoted to a consideration of certain phases of this reconstructive task. The thesis here set forth is this: What is demanded by the most urgent considerations of social unrest, today, and what is implied in the reconstructions of educational foundations, must be carried through in spite of the opposition of traditional institutions. 


\section{THE NATURE OF THE CONCRETE EDUCATIONAL PROBLEM}

In the primitive group-life, consciousness and responsibility were limited to the concreteness of the world of active relationships. Education was, therefore, completely social in character and results, because the whole of society was found in the concrete world of the developing individual. There were no social situations which lay beyond the possible experience of the individual, no scientific differentiations of experience remote from the practice of life. The educational processes were implicit in the community life-processes. The content of knowledge was in the social habits and activities, the results were such as had immediate application in practice, which were called for in the concrete social situations, and which were subject only to the general law of the elimination of the unfit. Throughout the period of plasticity and development the youth felt himself surrounded by the upholding, compelling, criticizing, and constructive forces of the social life. The educative processes were a part of the whole struggle for existence which the whole group was constantly facing, and they, therefore, carried with them the vital sanctions of life itself.

The results of such immediate processes of education could be stated, of course, in terms of complete social adaptation: the life of the group became the content of the life of the growing youth, and at his initiation into manhood he took upon himself, emotionally, all the content of the social purpose. In so far, then, as the social and the moral are identical, such education was completely moral; i. e., it organically included all the elements of consciousness and responsibility that the adult life afforded. Its lack must be stated in terms of the limited content of the life of the limited group - a lack that could be met only by means of social reconstructions that should be based on the inclusion of wider ranges of interest and activity within the group, the "cross-fertilizations of cultures," the development of a wider basis for a more complete consciousness and a richer personality. In the primitive world-a world whose control was largely extrinsicthis development could come only by means of the social shock of group conflict, conquest, and assimilation. In this way, alone, could group habit be broken and the possibility of larger and richer phases of consciousness be assured. Habit and the absorption of habit were fully provided for: the educational lack lay in the direction of that outlook which comes 
only in the reconstructive attitude, which is productive of the more inclusive social self-consciousness and which is deposited in the social inheritance in terms of theory.

But modern educational practices must function in a very different sort of world, and the changed world has come to realize that educational practices have not kept up their primitive organic and vital relatedness to the life-processes and social situations. The social and scientific phases of experience have grown very complex and become differentiated into the worlds of social and scientific theories under the forms of "sciences" which are more or less divorced from the immediacy of practice, and which lie, for the most part, beyond the experience of all save experts in each particular science. To be sure, there is a large body of common social habit, knowledge, tradition, popularized science, etc., which becomes, in some degree, the common possession of all members of a common society, and which corresponds to the practices of the primitive group, being perpetuated and propagated by the same sorts of primitive educational agencies. But It is within the limits of this popular knowledge that quackery and humbugs have their most persistent operations; it is the seed-bed of social prejudices and ignorance. Its traditions keep it from accepting progress? and save as its superstitions, mere opinions, and attenuated facts are broken through by some sort of process which sets the problem of reconstruction and conscious enlargement, there is no opportunity for either individual moral character, large reverence for truth, or the taste for the finer forms of beauty to thrive.

It is in the relation of individual and social activities to the more critical and constructive arts and sciences, which rise like mountain peaks beyond the borders of this common ground, that the educational, i. e., the moral and social, values are to be achieved today. Each of these sciences has its definite and vital relationship to the social life and possibilities of our times: each offers opportunity for the development of individual powers of appreciation and living; each offers possibilities of enlarging the sum of human controls of the resources of the world. Whether on the side of the physical or the social sciences, the opportunity is the same. Indeed, it may well be pointed out that the development of the physical world and its sciences has been a means to social differentiation and attainment, and that the enlargement of the social world has been made possible only in terms of the extension of man's control over, and reconstruction of, the world of physical means. For example, the only way the Roman could concretely think the Roman Empire was by means of the connecting Roman roads that ran to every corner of it; and conversely, the only excuse for 
building those roads lay in the extension of the social consciousness which demanded a concrete and continuous means of expressing itself.

But, today, theory has far outrun the possibility of concrete presentation to the common man: there are no "Roman roads" through the worldempires of most of the sciences by means of which they can be made concrete to the ordinary citizen. To be sure, the tremendous offerings of knowledge give endless opportunities for the satisfaction of all sorts of interests or curiosities, for the enlargement of funds of information, or for the enrichment of personality. And one can imagine a world of serious personalities, each with its own practical foundation in concrete interest, finding in the wealth of the world's intelligence opportunity to develop endlessly in chosen directions; using theory to make practice efficient and intelligent, and giving concreteness to the theoretical by putting it at work in the world of activities.

But, today, practice and theory seem, most frequently, to miss each other. Practice is impatient of theory and goes on its own way despising the "impractical," and ends, usually, in a blind alley of habit from which it has no power to escape. Or, theory feels itself independent of practice, is sure that if it "knows" it can readily "do" and goes on its own way. But in attempting to climb the mountains of pure theory, it too often misses altogether the meanings and relations science really bears to social living, and it becomes lost on the cold heights of mere theoretical consideration. Thus, the student of political science may forget, or despise, to vote; and the student of theology may miss or come to despise the love which "suffereth long and is kind."

Concretely, this sets the educational problem of the present. Traditionally, practice was secured in the social life and practical activities of the home, the farm, and the more simple social situation of the past; while the school came in to offer a complement in the way of theory. This theory was usually very remote from the actual life of the child; but so long as there was real practice in the mastery of life, the irrelevancy of the theoretical learning of the schools was not so noticeable. But when the city street took the place of the farm or the shop; when the flat took the place of the home with its round of social activities and interests, and when the isolation of the city's family-life took the place of the old neighborhood, with its oversight over growing youth, the old forms of practice almost completely disappeared; the school did not rise to this changed situation: the child was left, largely, to casual and meretricious influences at home and on the street, and to obviously irrelevant studies in the school. So the great educational problem becomes: How shall the educational forces that con- 
dition the development of the child be organized and controlled so as to assure the right amount of constructive practice for giving reality to the world and to experience, and the right amount of theory for giving everenlarging impetus to experience and intelligence in the control of the world, and the development of a constructive and responsibility-assuming attitude toward society?

Educational activity seems to be uncertain as to its proper direction in this emergency. Shall more practice be emphasized? The cry is immediately raised that such education tends to forget the old ideals of liberal culture, and to become merely utilitarian. Shall practice be ignored in the interests of the higher culture? The answer is pointed out in the overcrowded professions, and the shallowness of our ideals of culture, etc. One inevitable result of the present situation is to be seen in the bewildering number of different kinds of schools and "educations" which are demanding public attention and support. Many of these seize upon, and emphasize, some obvious aspect of the general situation, with impudent disregard of other aspects of the problem, or of the situation as a whole. Thus, we have schools of industry, trades, and commerce, covering every phase of the complex division of labor, and appealing to all who feel that the salvation of the world, at present, lies in the extension of practice, with but incidental regard for the elements of theory. On the other hand, there are the innumerable schools for professional, cultural, disciplinary, ethical, religious, and research interests, which largely ignore, and frequently despise, the practical phases of life. ${ }^{x}$

If, now, we ask what course, or courses, are open to present educational activity, and what prospects the immediate future offers of solution of these conditions, the reply seems to be indicated somewhat as follows: There are some who have especially strong intellectual tastes, who can "take on" ideas easily; these will want to fit themselves for the professions, the cultural arts, and the managing occupations; they are, therefore, to be educated along prevailingly intellectual and theoretical lines, with no special reference to practice during the period of educational preparation. There are a great many more who can hope to be nothing more than industrials all their days, who have little aptitude for ideas, and little interest in theory, and these must be content with a practice education for some industrial situation, with little reference to the higher intellectual or theoretical demands of the situation, or its implications for social life. While for both these classes these obviously imperfect forms of education are to be completed by means of some specifically "moral education" which

r Johnston, Educational Review, Vol. XXXVII, pp. I60 f. 
shall relate the individuals and their classes, in some way, to a more unified and human world. This study will be specifically devoted to the consideration of those forms of "moral education" which are related to this theory, but it will be necessary to keep in mind, all the way, the organic relationships of the whole problem.

We must not, however, lose sight of a very important fact: the most intelligent and constructive thought in education, today, is demanding that we shall stop talking about "professions" and "trades," with their connotations of class distinctions inimical to democracy; that we shall speak only of "vocations" for all; that, therefore, this overemphasis upon intellectualistic education for some, upon mere trade instruction for the many, and upon an exotic "moral education" for all, to serve as a humanizing of 'the mechanical, shall also come to an end; that in their place there shall be set up a more organic ideal of a properly liberal vocational education for all the differentiating aspects of life-an education in the very midst of life, which should carry with it its own moral inspirations and sanctionsand, finally, that this broadly liberal vocational education shall be for all, rich and poor alike, without exception. This ideal offers a suggestion of the line along which, ultimately, the divorce between theory and practice will be overcome; and in the working-out of this hope the unity of the primitive world of social education will find its way back into our modern life, carrying its highest moral controls and sanctions in its own activities, not implicitly, however, as in that primitive world, but consciously, now, and explicitly.

But it must be added that, however desirable such a consummation may be, no one is able, at present, to offer working details of a method by which it may be realized. This is the largest constructive educational task that our educational thinking has formulated. In comparison with it the task of experimental determination of the mental conditions under which certain specific forms of "learning" may be most advantageously carried on is child's play. The full statement of the problem may be given in some such way as this: How shall we relate the various partial forms of educational activity of the present systems to the complete and concrete unity of the social process, so that these partial aspects of life shall be made to open out upon that world of complete human activity, in which, alone, whether for education or for occupation, the individual can actually find the social support, coercion, and constructive criticism which give vitality and meaning to individual endeavor? How shall the implicit values of primitive education be restored in explicit form in the complicated world of the present? 
This question will always be relevant, even though the ideal mentioned above should be in large measure realized. For even a vocational education may lack some of the elements of social self-consciousness, social outlook, and acceptance of a share of social responsibility which are necessary elements in the genuinely ethical life today. It is not enough that the individual be honest, industrious, frugal, and law-abiding. It is essential that he share in the life of the world, which is his social community, as the primitive man shared the life of his world. So whether for the present situation, or for some future condition, the consideration of the moral phases of educational activities is a task that must be thoughtfully faced and constructively handled.

To the critical consideration of some contemporary treatments of this subject we must now turn. 


\section{THE NATURE OF THE MORAL IN EDUCATION: SOME TENTATIVE ANSWERS}

The universal demand for an educational practice that shall secure larger moral results has already been noted. We need not dwell upon the ideal, but attention may be called to the fact that this demand is taking deeper and deeper roots in social consciousness, local, national, and international; and that it is expressing itself in the form of criticisms of present practices and theories, in hints and schemes for the remaking of present practices, in national and international conventions for the spread of information and the deepening of the social consciousness of the world, in national and international inquiries for ascertaining the exact status of the moral-education situation in all parts of the world, and for the securing of a new and definite foundation upon which to build wisely and widely. The problem is not a local one, for the world is no longer made up of local and isolated communities. In reality, the problem includes the worldwide situation: the individual lives in a community that has relationships with the ends of the earth, and that draws its support from all lands. We share the offerings of all the world: our food, our clothing, our ornaments, our household comforts, our implements, our amusements, our ideas, and our ideals-who shall say whence all these come to us? To be sure, there is a fallacious popular political economy and social ethic that teaches that an exchange of services can be carried on on the impersonal level; that, e. g., eating the rice of Japan, if we have fully paid for it, we are in no sense morally related or bound to the producers of it. But the higher social consciousness is able to see the essential moral nature of all human relationships, whether between neighbors in the same flat, or neighbors on the other side of the world. Our moral relationships are as wide as our commercial relationships. The problem of moral education is to determine how these moral relationships which are unrecognized and implicit in all our world-life, both in the immediacy of the local community and in the largeness of the world, shall become explicit and effective in social consciousness. But, before we take up the intrinsic logic of this problem, we must turn to the consideration of some of the ways in which the facts are being conceived and treated in contemporary educational thinking and practice.

Just as the common conceptions of general educational practices are 
thoroughly provincial in form, so it seems difficult for many to see the larger aspects of this problem of the moral elements in education, and their relations to the whole social problem. For the most part, of course, this provincialism is due to a lack of psychological insight; moral education is confined to special provinces of life, or it is in terms of special materials; the impartation of particular ideas, called moral, or the working-up of special forms of feelings and sentiments, or the production of that abstract Kantianism "a good will," with no convincing insight into the processes by which these very desirable elements do really develop. We shall note, here, some of these ways of handling the problem.

Much of the present-day insistence upon moralized education finds its psychological warrant, as well as its historical background and justification, in the psychology and pedagogy of Herbart, and the work of the Herbartians in Europe and America. In general, this constructive movement has stood for a direct method of moral instruction, claiming for this method the authority of Herbart's psychology, which asserts that all our mental faculties, including the will and conscience, are rooted in the "circle of thought," and, therefore, that education consists in introducing into this "circle of thought" ideas which shall act powerfully in the production of a good life. There is a very insidious charm in the simplicity and comprehensiveness of this theory. So great is this charm, and so insidious, that Professor John Adams has said: "Even if this theory is not true, teachers ought to wish that it were, and to act as if it were." The general pedagogical principle has been fully exploited in Europe and America. In America the effort has been sustained by the National Herbart Society, and for a time it seemed that "Herbartianism" would become the actual basis of all pedagogy. Great good has come from the work done by this society, and the yearbooks of the society are filled with valuable materials. But to a large extent the most valuable materials are those which have been called forth in criticism of the general point of view. ${ }^{2}$ The criticism aroused has been exceedingly fruitful, and the certain end of the Herbartian propaganda is to be seen in the fact that the National Herbart Society has become, in recent years, the National Society for the Scientific Study of Education, giving up its propagandist tendencies and taking up, seriously, the actual scientific study of the problems which underlie the realization of a scientific pedagogical practice.

But in England the vogue of direct moral instruction through the use

I In some unpublished lectures.

2 Especially the work of Dewey; e. g., "Interest as Related to Will," in the Supplement to the Third Yearbook. 
of this Herbartian principle seems to be gaining strength. The Moral Instruction League of England issued, in 1908, a circular entitled Moral Instruction-What It Is and What It Is Not. Here moral instruction is defined as the "training of the children's feelings, judgment, and will, in order to insure that they play the part of good citizens in the family and country and as members of humanity." This is, of course, a very high ideal, a "consummation devoutly to be wished." But it is to be noted by way of criticism that this ideal assumes the existence of the child's feelings, judgment, and will, prior to the training, as faculties, and that it undertakes to train these pre-existent "faculties" to certain specific ends. In further explanation the statement of the league goes on to point out that "moral instruction proceeds by means of set lessons or conversations definitely directed to moral subjects." A list of these "moral subjects" is given, as follows:

The subjects of moral instruction comprise temperance (i. e., general selfcontrol), courage, patience, prudence, perseverance, kindness, generosity, mercy sincerity, truthfulness, modesty, conscientiousness, honor, industrious habits, justice, probity, right use of wealth, social service, duties of citizenship, respect for various forms of religious belief and practice, co-operation, international fraternity, art and nature, ethical elements in history, biography, and history.

In a single paragraph the ideal of "moral education" as distinguished from "moral instruction," is set forth as follows:

Moral education embraces a much wider field. It may or may not include systematic moral instruction in the essence just defined. It seeks to give a dominant ethical tendency to the whole process of the child's training in the home and school, by lessons that call out the social sentiments, by studies that exercise the moral judgment, by occupations that discipline the will to mutual consideration and service, and by impressing upon the imagination the duty of subordinating all intellectual and practical activity to the common welfare.

This is all the league has to say on the broader aspects of the subject; and even in these few words the child seems lost under the burden of external institution and idea, and a sort of forced altruism that must be assimilated in rising to the level of "common welfare." The primary interest of the league is in moral instruction, and its more detailed explanation of the processes of this instruction throws light upon the league's conception of educational activity, in general. In answering the question, What is moral instruction? the circular states: (I) "It is an interesting presentatation of the facts of the moral life." (These "facts" are said to be "judiciously selected instances of men, women, and children engaged in active 
well-doing." But there seems to be no conception on the part of the authors of the circular that such "facts" are not facts at all for a child, but, for the most part, and save as consciously controlled by the teacher, they are abstractions, pure and simple, out of a world of unrealities.) (2) "It trains the judgment by reasoning and questioning." (Again, it is pointed out that the reasons and questions are related to those selected instances, for the sake of unity. But this makes of judgment and reasoning highly intellectual and abstract functions, instead of vital and concrete processes of realization of meanings and adaptation.) (3) "It draws from an unrestricted variety of sources." E. g., "A simple lesson in astronomy brings out the idea of law and order as revealed in the motions of the planets, of the regular and inevitable results of the earth's seasons, tides, etc.; and the children may then be led on to the conception of obedience to natural law; while this again prepares the way for obedience to social obligations. And so in other sciences." (4) "Its area is co-extensive with all ages and all nations."

But we need not dwell longer on this commonplace and external method of dealing with the vastest issues of education. There is another aspect of direct moral instruction that has had its support in an appeal to some emotional constituent of experience for additional sanction. This additional sanction has usually been found in religion, though at times in other of the higher emotions and sentiments. There-are some who affirm that moral education is impossible without some such appeal, and that mere moral instruction of the direct sort is useless, if not impossible. "Without religion the teacher has no basis for reproving a child for wrong-doing. He has nothing to put before him as an encouragement for doing good, or as an explanation of what he wishes the child to consider bad. There is nothing to give the child's mind the capacity for understanding the difference between right and wrong." At the International Moral Congress of 1908 , Dr. Felix Adler insisted that moral education should be left entirely to voluntary associations because, he said, it is impossible to impress moral ideas without direct or implied reference to some fundamental religious or philosophical system, and the state must not bring such things into its schools. The utter formalism of this conception does not seem to be readily apparent. The unrelatedness of such teaching can be seen in the German schools, where a complete system of moral, or religious, education, based upon this sort of theory, is carried on; and in France, where a more definite system of moral education, based upon patriotism and "the sense of sociality," using as its text, not the Bible, but the "sacred book of the human soul," is in vogue. Both in Germany and in France the teaching 
is under state control; and in both countries the results are intellectual, and not vital and personal, save with the few who can understand.

For direct moral instruction, whether based upon its own intrinsic meanings, or upon some emotional appeal, does not seem to get into the heart of the problem. Hence, there is a growing feeling that some indirect form of instruction must be devised by which moral results can be secured in the regular course of education, moral materials slipped into the educational activities without betraying their real character. But there is a conflict of opinion here. Can moral results be secured in such ways? At the International Moral Congress of 1908 this question aroused long debate. Canon Glazebrook held that moral instruction could come only from history, literature, and the Bible. To try to get moral lessons out of arithmetic was to revive the errors of Pythagoreanism. But Mr. Gustav Spiller held that all subjects might be made to yield ethical lessons without violating the facts. Mr. Gautrey, of the London Teachers' Association, held that moral education of the child should permeate the whole course of instruction. It should not be confined to particular lessons, but it should be the atmosphere, the spirit of the school. But he did not tell how this was to be brought about.

But, on the other hand, can so-called "moral materials" be introduced into the school activity in such a way that they will produce moral results by indirection? Can morality be smuggled into a child? Several "systems" have been proposed to this end. The "Brownlee System" centers the work of the school, for a month, around some "moral" word, e. g., temperance. This word is engraved on banners hung about the schoolroom, it is on banners carried in the school marchings, etc., and it is made the subject of five minutes' conversation in class, daily during the month. Living with this word for a month is supposed to teach it thoroughly. It is explained that the psychology underlying this is: "Thoughts are things"; i. e., if the child can be made to think the idea long enough he will become possessed of the idea. But, of course, the real psychology of the situation, in the majority of cases, will be that acts produce habits, and habits are impervious to mere ideas; so that before the end of the month most of the children will have become wholly immune to these extrinsic ideas.

Another "system" of the same general character is the so-called "Fairchild System"-"The New Moral Instruction." The announcement of this system says: "Character has always been asserted by American educators to be the chief concern of education, but, heretofore, no satisfactory way of teaching morals has been available." But now "A new 
moral instruction which is surprisingly influential and interesting is offered for general use in American schools." This new system is explained as follows:

(I) A short course of "illustrated morality lessons" as text lessons (i. e., a stereopticon lecture on morality). The photographs are all from real life and the moral convictions of the best people are explained in practical application, so that the discussion seems important to the children, and carries influence. In time there will be a course of thirty-six, three for each year of primary, grammar, and high school. (2) A special instructor employed by the board of education in each large city, to deliver the illustrated lessons in school assembly halls throughout tise city. (3) Review and discussion, enforcing the assembly instruction, by teachers and principals. (4) A corps of traveling instructors to serve smaller cities, churches, settlements, etc., each assigned a district and headquarters. (5) A supply of text lessons to be provided by the Moral Education Board, an educational philanthropy representing all interests and self-supporting through rentals and lesson-fees.

This plan comes recommended by many prominent citizens and educators, and the Moral Education Board is made up of representative men and women from all parts of the country. These lectures have been given before audiences in many colleges, high schools, grade schools, churches, etc., and the testimonials presented show that a real effect has been produced. Among the lecture titles are the following: "What I Am Going to Do When I'm Grown Up, or the Utility of Education"- to be given in the upper grammar grades; "The True Sportsman, Ethics of Athletic Games"-for the high school; and "What Men Think about Boy's Fights, or Problem of Personal Encounter"-for the lower grammar grades.

There is no doubt that these lectures can be made to yield some valuable results. But it is too much to claim that this is a solution of the problem of moral education, or even of moral instruction. It has the inherent vice of all the traditional educational practices-it expects the child to absorb ready-made ideas. The fact that these ideas are the "moral convictions of the best people" does not answer this criticism. The whole conception of modern education is centered in the creative activity of the child; certainly that activity cannot be dispensed with in this most intimate world of moral ideals. The real values of this system are to be found in the statement of one critic that it is a sort of "moral nickel theater." As an attempt to utilize the amusement methods of the cheap theaters for moral ends it has a wide field of possible usefulness.

With no intention totally to condemn these efforts toward a more com- 
plete educational practice, it still may be pointed out that they show the survivals of antiquated points of view in the sciences which underlie education. The psychology of both the direct and indirect methods set forth above is of the association type-good psychological doctrine in the days of Herbart, i. e., in pre-evolutionary times. Its fundamental error was in its insistence upon the intellect as the primary factor in mental life, and its consequent ignoring of the logic of development, and the place of activity in the processes of growth, with its corollary, the idea as an instrument of control. The ethics of these systems shows a like error. There is an overemphasis upon the part which society contributes to the development of control, a burdening of the child beneath the weight of social habits and institutions, and a complete ignoring of the creative activity of the individual in the moral world. Over against all these attempted solutions of the problem of moral education we may set the simple statement of Professor Foerster: "The ethics of the future will be based upon the evolution of the inner life."I

There is one other interpretation of the present situation, with accompanying tentative solution, that must be discussed before we leave this division of our subject. This discussion of the situation is especially worthy of consideration because it shows a tendency of educational thought and practice away from the extreme intellectualism of the previous systems and in the direction of a more functional interpretation and construction of the world. According to this present point of view, the solution of the present problem in education can be secured only by carrying the whole process of education back into a corporate community, resembling the primitive community-group, in which the educational activities shall be implicit in the whole organization of the group, and by means of which those activities and processes shall secure the immediacy of appeal, and the vitality of sanction which they held in the primitive group. It is held that if such a corporate life could be organized it would assure the completeness of education which primitive education possessed.

In England, this ideal is appearing under the concept of the "corporate life of school." ${ }_{2}$ It has its warm defenders, especially in the great public schools, in which, since the days of Arnold at Rugby, something of this ideal has been present. The plan as at present operative has been described in detail in the literature. The school becomes a sort of organic and self-sufficient group, in which certain educational activities, forces,

x Bibliothèque du Congrès International de Philosophie, Vol. II, pp. 403-I2.

${ }^{2}$ See articles of J. J. Findlay and H. Bompas Smith in Moral Instruction and Training in Schools, edited by Professor M. E. Sadler (London, 1908). 
ideas, ideals, sentiments, and wills are active; and it results in the complete adaptation of the individual to the situation, or, in the event of his lack of adaptability, in his expulsion from the group. There is much to commend in the plan as proposed. There is need of a more unified world in which the early developmental processes can be carried on, in terms of the absorption of social habit rather than in the presence of the disintegrating influences of the overstimulating conditions of the full blare of our world-life, today.

But the general discussion of the proposition usually neglects or ignores the more fundamental fact that no isolated concrete community, such as a school, can fully represent the world of action today, and that, accordingly, the practice in social habits attained in such a community will not insure complete social functioning in the larger community of the world. Indeed, practical schoolmen in the English public schools are recognizing and calling attention to the practical failure of this proposed solution. At the International Moral Education Congress of 1908 Sir Arthur Hort, headmaster of Harrow, asked: "Why does the sense of corporate life once gained in a miniature world not more often develop into patriotism and similar virtues?" And Professor Muirhead, before the same congress, said:

The virtue of patriotism or solidarity, as taught and practiced in schools, is of a narrow and exclusive kind. It trains a boy to give himself up for his cricket club, his school, or afterward his college; but it rarely extends beyond the school or the college to the university or the country at large. A public-school boy will do a great deal if you appeal to him on the class side, but he is deaf to all appeals from his city, his county, or his country.

This discussion has carried us into the heart of the psychological problem of the possibility of "generalized habits," or the transfer of training from one field of activity to another, more or less related. The fundamental reason why the public-school boy does not carry his school habits over into the world of action is to be found in the fact that there is a fundamental difference between the school community and the world community, and habits are related to likeness of community. Habits built up in one community will function in another community sufficiently like the first to offer the sufficient stimuli. But the school community and the world community of the present are essentially unlike, and they cannot be made like by any such isolation of the school from life. The school community, as isolated in the English public schools, is a concrete community of the primitive sort, in some degree. But the world community of today is not concrete: it is highly abstract, both socially and scientifically. It gets a certain amount of concreteness in terms of transcontinental railroad lines, 
world-encircling steamship lines, telegraph and cable lines, wireless telegraphy, international diplomacy, world travel, international magazines, etc., but in the main it is a great abstraction.

Now, recent experiments in the transfer of practice, i. e., habits, from one field to another, have shown that in so far as the habit can be mediated to consciousness in terms of its appropriate ideas, the transfer can be more or less successfully made; and as an educational principle, where the habit does find its expression in terms of ideas, the teacher may expect to find it actually carried over and applied in wider fields. But not alone does this give wider range of practice: it also, and this is the more important aspect of the case, gives a wider range of consciousness, a larger grasp of ideas and theoretical phases of experience, and consequently it allows the individual to enter more fully into that abstract community-the modern world.

It would seem, accordingly, that not even the corporate life of school can be counted upon to solve our problem; for its results are partial on the side of practice, as the results of the traditional education are partial on the side of theory: the former ends in practice, in social adaptation, whereas the only satisfactory end of education, today, is adaptability; the latter, i. e., traditional education, ends in mere theory, whereas the acceptable end of modern education is theory at work in construction and reconstruction of the world - in control-in power to meet and mediate social changes.

What, then, shall we say? It were, perhaps, too much to say what Bacon said to the men of his times who held to the older ways of looking at the world; but with much allowance for the violence of his language the point of his remark is still pertinent, especially the last sentence. He says:

If there be any humility toward the Creator, any reverence for or disposition to magnify his work, any charity for man and anxiety to relieve his sorrows and necessities, any love of truth in nature, any hatred of darkness, any desire for the purification of the understanding, we might entreat men again and again to discard, or at least to set apart for a while, these" preposterous philosophies which have preferred theses to hypotheses, led experience captive and triumphed over the works of God, and to approach with humility and veneration to unroll the volume of creation, to linger and meditate therein, and with minds washed clean from opinions to study it in purity and integrity. For this (i. e., nature) is that sound and language which went forth into the whole world and did not incur the confusion of Babel; this should men study to be perfect in and becoming again as little children, condescend to take the alphabet of it into their hands, and spare no pains to unravel the interpretations thereof, but pursue it strenuously, and persevere even unto death (Nat. and Exp. Hist., VolI X, pp. 370, 37I).. X 
Is it possible for us to take into our hands the alphabet of experience and, in terms of the foundation sciences, patiently linger and spare no pains in the effort to interpret the actual method of experience, and, in terms of its actual processes, to construct the broad lines, at least, of the educational theory which shall vitally and fruitfully determine educational practice? To this problem we must next turn. 


\section{THE NATURE OF THE MORAL IN EDUCATION: AN ORGANIC STATEMENT}

The results we have reached may be briefly restated, as follows: There is a growing demand for educational reconstruction-a demand that has not yet achieved much, because of uncertainty of method and the need of keeping the machinery moving. There has been much reconstruction of educational theory, but this reform has not penetrated deeply enough into the common consciousness to result in consistent reforms in practice; nor has the reform in theory carried with it the definite condition that its acceptance will presuppose a complete revolution in educational practice. There is much unrest, much talk about ideals, much longing for better things, much more or less naïve effort to secure incidental reforms, much pseudo-scientific experimentation, much uncertainty as to what ought to be done, and but very little practical result. The press of affairs is bringing about innovations, some of which do not approve themselves to the best thought of the day. In the midst of the situation there is almost no large leadership-there are certain tendencies, and that is all. On the side of moral education there is a growing skepticism that expresses itself in the effort to secure moral training by some method of indirection. The need of the times seems to be a fundamental re-examination and reconstruction of the foundations of education, under the leadership of modern psychology, logic, and ethics, and a profound restatement of educational theory in terms of these results. This theory must be completely functional and instrumental, keeping close to the demands of both the world community and the individual's processes of development. It must detail the processes by which, in concrete reality, the child attains the maturity of its "power on its own self and on the world" which is the mark of the educated man. In this study we cannot hope to cover the whole field. But on the basis of what has already been set forth we may be able to deal with so much of this field as may be necessary to show the organic foundations upon which a vital moral education must be grown, and the organic processes which must be used in promoting and securing that growth.

Our foundational presuppositions are to be found in scientific reconstructions of psychology, logic, and ethics, whether this reconstruction "be termed pragmatism or be given the happier title of the applied and experimental habit of mind." Functional social psychology, instrumental logic, 
and the ethics of the inner life of developing control-these must mark out our way. In the course of the argument the specific demands of each of these will be considered briefly. Here it is necessary to make a brief statement of the lack which is felt, and which the so-called "moral education" is expected to supply. It was pointed out in a previous section that much of our knowledge, today, is divorced from any real experience, that it is merely "erudition," in the invidious sense of that word; and that, on the other hand, much of our practical activity is merely "rule of thumb" practice, though the actual knowledge by which it can be made intelligent. is probably within the experience of men, somewhere. It was shown that these two phases of experience are pointing the ways to two distinct tendencies in education, one in the direction of theory, with little reference to practice; the other with an emphasis upon practice and with little care for the broader intelligence that can give practice its highest human meaning. Each of these is, of course, partial and illiberal. And we face the distinct problem of an education which shall include the good in each of them, and reduce the evil to its lowest terms. How shall the incompleteness of class education become the completeness of a really human sort of education? How shall this illiberal fragmentariness be done away, and the larger and more universal outlook and the more liberal spirit take its place? The man of science, or art, or philosophy, is dependent upon the world of industry in a way that, at present, he does not like, always, to admit; the man who labors with his hands is dependent upon the man of ideas, the world of theory, in a way that, for the most part, he neither realizes, nor cares to consider. We need not discuss which is the more immoral, the snobbish superiority of theory to practice, or the pathetic glorying of practice in its "practicality." Both are serious. The world is one community, today; and this adds to the complexity of this problem: there are social relationships upon which we are all dependent, but of which we are all more or less ignorant, and upon which we do not always choose to inform ourselves. The lack in either case is much the same, though seen from different points of view. The man of science needs to become conscious of those elements in the social world which the workingman is contributing to his welfare, and to interpret those contributions, not in terms of impersonal relationships, but as the contributions of personalities,' selves, like himself, to whom he owes the same sort of moral responsibility that he exacts from them; and the workingman needs to become conscious of the implicit relationships of dependency which he sustains to the man of the other class: each-both-need a developing social consciousness, in which these implicit relationships will be coming more and more into explicit 
realization-into the determination of the larger sense of social fellowship and responsibility, and in which each shall be interpreted as a personality to the other-no longer as mere means to life, but now as ends in themselves, and fellow-members of the social "kingdom of ends."

Tentatively, and in brief, then, we may say that the lack which "moral education" is expected to supply is that social consciousness in which the self and all other selves that relate to the world of the self shall appear explicitly, and in terms of which individual responsibility shall become identified with the social good. And this shall serve as the definition of the "moral" which is sought for education, until we shall have developed the argument to a point where more detailed statements are possible. It will not be denied that this is an essential constituent of education, and that an inquiry which seeks to determine the organic foundations of this constituent, and the method of making it real in educational results, is pertinent to the situation, today, even though such an inquiry must neglect certain very valid elements in the general problem. For, whatever the end which any particular interest in education may have in view-profession, trade, vocation, knowledge, culture, or any other end-this element which is here called the "moral" has full right to come in, either as a supplementary end in itself, or as an integral part of the proposed end; indeed, it has not only the right to come in, but, rather, no education can be called more than mere instruction which does not contain it.

Stated formally, then, the end that is sought in the effort to make education moral is the development of a social self-consciousness which not only implicitly receives, but explicitly understands and gives in return. But this formal statement must be given fuller meaning. Psychology must be asked to give the concrete setting of this consciousness in individual and social living; ethics must be appealed to, to give it content of personal purpose and social relationships; and logic must come in to give the method of the concrete realization of this content in actual social practice, i. e., in educational activities. These will be taken up in order, and the effort will be made to set forth the organic and functional relationships of this educational end to the whole of the concrete and developing experience.

\section{A. THE PSYCHOLOGICAL POINT OF VIEW FOR MORAL EDUCATION}

The central aim in education-the aim which the emphasis upon the moral really represents-is the self, in its world of social and physical relationships, and conscious of the existence and meaning of those relationships in terms of its own experience. This central concept of the self is the object of knowledge of social psychology. Social psychology attempts 
to trace out the actual conditions under which, and the intimate processes by which, the self, or selves, of concrete experience, i. e., of social and moral relationships, arise in consciousness. General functional psychology deals with what it calls the "adaptation of the organism (human or other) to its environment." But education is interested in a much more intimate study: the actual development, enrichment, and adaptation in terms of rising levels of self-consciousness, of the selves of everyday experience. The so-called "educational psychology" of the past has been, in large degree, a description of processes that seem to be going on inside the individual. But educational practice really needs a psychology which can deal with the individual and his development as integral parts of the general evolutionary process, and as a potential member of the social world. Social psychology is at present attempting to work its way through this field. Its results are not.conclusive as yet, but a rich field has been opened up; and the general spirit and purpose make it most available as an aid to educational activities.

Genetically, the basis of the self is in the native activities, the instincts and impulses of the child. This activity is the presupposition of consciousness, and an ever-increasing complexity of activity is the presupposition of self-consciousness and its development into a social world. Rather, when the self finally rises into consciousness, the social world is already therethe self and the other rise into consciousness together. This is true also of consciousness of objects. In the earliest life of the child consciousness "must be relatively as unorganized and lacking in definite meanings as are the overt activities that go along with it. . . . . At first undefined, it grows in definiteness of reference of content as activity becomes more and more complex." That is to say, consciousness grows in terms of the activity by which growing experience constructs the world. This constructive activity has a twofold reference. Comenius speaks of an "old proverb" which says: "We give form to ourselves and to our materials at the same time." The activity of the child is, from the very first, constructive. It is giving form and meaning to the objects and persons which make up its implicit environment; at the same time it is giving content and definition to the consciousness which is slowly becoming organized into an intelligible world.

Consciousness rises at the point of failure of instincts to secure the sort of experience which the moving current of activity expects. Tensions of this sort begin early. Each such situation requires an increment of organization for its solution. Out of the growing aggregate of these increments the central "core" of constructed powers is organized. But each such 
intensified situation carries with it a degree of emotional disturbance. This emotion serves a double purpose, related to the twofold nature of the creative activity which is here present. On the one hand, the emotion serves to evaluate the conflicting terms in the situation, and to give to experience a standard of value to be used in the choice of ends, or in the construction of a unified end: thus does emotion function in the construction of the world by insuring a world that shall have value to the self. On the other hand, this emotional situation really consists in the struggle of these ends to be realized as possible selves: it is a struggle between potential selves, and out of this struggle a new and larger self will actually appear, an integral part of which will be the increment of emotional value which the struggle created: thus does emotion function in the building-up of the self, by making it equal in value to the world it has created. Thus the self and the world arise together in consciousness: the values which are present in the one are present in the other also, for those values arose together in those various creative experiences out of which both the self and the world have grown.

Now, primarily, consciousness is social in character; i. e., the first stage in the development of the conflict which conditions the appearance of consciousness is the emotional one, the stage in which impulses to activity, or ends of desire, appear as potential selves-as members of a social world. This is the prevailing character of the consciousness of the child and the primitive man: for these, the differentiation of objects as "things" as distinct from personalities has not yet taken place. And this differentiation does not take place until the individual has reached a degree of organization of his mental processes sufficient to assure the control of the materials by powers that can rise above the level of emotions, and look upon the situation as a whole, and assign to each element its proper place in that whole: personal and social elements to their place in the unification of the end of action, "things" to their place in determining the means by which that end is to be realized. This unified end gets new value, for it is the self that is to be; but it is also a less impulsive and more rational self, for it has been criticized in terms of the means of its realization; that is to say, is has definitely grown out of, and is intimately related to, the whole of the new experience-world.

This differentiation of the social from the "thing" is not to be confused with the earlier implicit recognitions of the differences between my self and other selves, or the fact that my body is not continuous with other objects. The general feeling for these differences may be present early in experience, but not in terms of the definite differentiation between per- 
sons and things. This latter fact is rather late in making its appearance. With many it never becomes an assured fact; and it is easy for all of us to fall back into the attitude of primitive animism, and to present all the world, again, in terms of a social consciousness. This is what we actually do do in that first stage in the solution of problematic situations during which the conflicting ends occupy the whole attention, for these present themselves in emotional coloring and warmth as possible selves, i. e., in a social setting. The complete differentiation of these aspects of experience is a function of the growing complexity of experience, of developing consciousness, of power to present the world as a whole and in parts, of mature consciousness.

The point to be emphasized here, constantly, is this, therefore, that the self does not exist, ready made, with powers that are to be trained. For social psychology, and for education, too, the self and the world arise together in consciousness; the powers of the self have to be developed, through the development of a world calling for those powers. The self reflects the world that it lives in, i. e., that has risen into consciousness with it. Education has, accordingly, the problem of providing for such creative situations in the developing experience as shall insure the rise of the larger self, and the more inclusive world. "The function of education in a progressive nation is not merely to develop habits suited to a present condition of life, but also to develop adaptability that will enable the individual to fit himself to new conditions as they appear. But adaptability is a function, not of habit or instinct, but of attention, of intelligence, of consciousness."

Two phases of this situation obviously differentiate themselves at this point. The first has to do with the conditions and processes of development by which the child grows from its early undifferentiated status to its later consciousness of self and its specialized power over the world. This is specifically the problem of the logic of experience and will be taken up in detail in its proper place. The second phase of the situation has to do with the way in which the mature individual achieves that completel differentiation of personal and impersonal elements which gives concrete content to his social self-consciousness and actually makes him a completely moral being. This, of course, cannot be completely differentiated from the logical problem: in concrete experience all these elements join to make the concrete unity of life and experience. But under the discussion of the ethical problem in education we shall deal with this phase of the complete process of development. It thus becomes apparent how soon the problem of psychology becomes differentiated into these more special problems. A complete discussion of this situation would demand the consideration of 
the aesthetic phase of experience, also, but this would unduly prolong the treatment, though the point of view will be briefly treated.

With a final word as to the problem of education from the point of view of social psychology, we shall turn to the other special phases of the discussion. From this point of view, education is seen to be the slow development and differentiation of experience on the basis of the native activities, instincts, and impulses. On the basis of these native powers habits are slowly organized, which bring an ever-increasing range of the world under the power of experience. But the world is increasingly complex, and instincts, impulses, and habits will be continually breaking down, and experience will be thrown back upon the necessity of reconstruction, which will involve the rise in consciousness of a fuller social world, and in time the differentiation of the world of ends from the world of mere means to those ends; but this development will also be both cause and effect of the development of the perceptual, presentational, imaginative, conceptual, reflective, and judging powers, as distinct from the mere feelings and the overpowering emotions. All these powers can be abstracted from their setting in concrete activity, and can be made the objects of education or training: thus, in the past, has education been intellectualized, and life has been robbed of its concrete content. Ideas have been presented as pre-existent -emotional and religious sanctions have been appealed to, to give these formal ideas and powers logical value in experience, and the whole world has been turned upside down, because of a mistaken point of view in psychology. Today, educational psychology ought to become the technique of the organization of developing experience, with the conscious power to keep that experience constantly related to the real world of action, yet as constantly integral within its own but partially developed content and power. In this way will the teacher be able to see and to control the correlative developments of the self and the world in the consciousness of the child, and to make sure that the child's real world shall be a world of its own constructive experience, within which it can move increasingly as master. Thus will the conscious world always be the correlate of constructive differentiations within the experience. And thus will need of a reconstructive attitude toward experience be built up and always maintained. And thus will the moral end of a social consciousness and power of adaptability be secured.

We must now turn to the problem of stating the more complete content of these formal terms that we have been using to this point. That content will appear in the discussion of the ethical point of view, and that will set our next problem. 
B. THE ETHICAL POINT OF VIEW: THE CONTENT OF MORAL EDUCATION

"Mental development is, at its best, the revelation of an expanding, variegated, and beautiful whole, of which the right act is a harmonious member." But it is difficult for moral education, or for any sort of education, save, perhaps, aesthetic education, to take any such developmental point of view. It seems so evident and obvious that the world has wrought out certain results which exist for the individual, and there is a general feeling that what the world has once done, the individual may be excused from doing. We are the "heirs of the ages"; we "stand upon the shoulders of all the past"- this is the general point of view. Over against this we need to remind ourselves that, as Professor Foerster says, "the ethics of the future will be based on the evolution of the inner life." Our problem is to give this evolving inner life content, and to point out the pedagogy of this point of view.

It is a fundamental postulate of modern ethical theory that the moral life is an achievement of the individual-of course in the midst of a social world - that the moral values of the world's experience become values in the individual's experience only as he re-creates them in vital situations which his own experience unfolds; and that these values arise in terms of the same logic of experience that brings about the development of our so-called scientific values. ${ }^{\text {I }}$ This last point will be dealt with later: here we are concerned with the actual content of the moral life as it grows in concrete experience.

It is the business of modern ethics to give the historical and the psychological description of the processes by which moral values are realized. But in the main, no dogmatic statements as to the actual content of morality are made. "The student is put in a position to judge the problems of conduct for himself. This emancipation and enlightment of individual judgment is the chief aim of theoretical (ethics)." ${ }_{2}$

From this point of view the question of content seems futile; and yet it seems to be just the most necessary of questions for the educator: What shall be the content of moral education?

In order to make the problem more specific, let us note that the common point of view referred to above posits a certain mass of materials which are by nature moral, and which it is the business of moral education to inculcate. We have seen this method in detail in a former section. Moral precepts, rules, and ideals are to be forced into the individual, in some way;

I For a full discussion of this point see Stuart's essay, "Valuation as a Logical Process," in Dewey, Studies in Logical Theory, p. 227.

2 Dewey and Tufts, Ethics, pp. iv and v. 
usually this has been accomplished in terms of mere memorizing which goes no farther than a parrot-habit which can repeat the words, when the proper stimulus is given. And, when this defect is pointed out, the ready answer is, that the memory will hold these things until such a time as the experience will be in need of them, and then they will spring into life and vitality of meaning; or, at any rate, while the child is learning these good things, he is kept out of mischief.

Of course, there is a good bit of fundamentally bad psychology in this statement. Comenius pointed out long ago that "actual knowledge, virtue, and piety are not given to men. These must be acquired by education, by action, and by prayer." And our more recent psychology and logic of ethics has shown that the genuineness and reality of the ethical values depends upon their vital connections within experience, and their relevancy to the situation in which they are supposed to function. Recalling our discussion of the rise of the self, or of selves, in the previous section, we may say of precepts, or rules, or ideas of any sort, that they have value for the developing self only in so far as the self which uses them is identified with the self which gives them. That is to say, if the precept calls for action-and of course, it is valueless otherwise-it becomes a social element, i. e., it is the heart, or the will, of a self acting in a social world, and it is only as this precept-self is actually identified with the self whose experience wrought out the precept that it actually enters into an experience that has content of meaning. At any rate it is certain that the child does not and cannot make use of the impersonal precept, for the child lives in a social world as yet, and cannot understand the language that is talked down to it from that level of abstraction where the personal and the impersonal have been fully differentiated.

Again, from this standpoint of the moral as material which already exists, we have the constant problem of working up the motive forces which can make this "moral knowledge" become real in moral action. This is an age-long problem. In that first great break between the world of immediate experience and the world of social theory, which grew out of the questionings of the sophists and the work of Socrates and Plato, this question arose: ideas are standing over against the immediacy of experience; the ideas seem good to some, but the many seem to be able to get along very well without them; how can idea and experience be brought together-can the Good be taught ? The problem comes to mean: Can the controlling ideas which will some day be needed in order to lift the self out of its genetic thrall to immediate impulses, instincts, and the developing world of habits; or by which its immediate experience and its power over the world in prac- 
tice will be saved from overwhelming multitudes of mere instancescan those ideas be taught before the life has need of them? Of course, this question is based on bad psychology and on mistaken conception as to the nature of the Good-though these mistakes are really identical. The mind of the child does not peer into the future, or into experience outside its, own range, for ideas, precepts, or rules that may some time meet some problem which has not yet arisen. Not only can one not learn what he is going to need at some future time (until one has formed a lifepurpose and has centered his learning about the generalizations of his specific problem), but he cannot even guess at it in any exact way, for unless he allows his life to settle down into the impassiveness of the habitual and the mechanical, the future will be full of problematic situations, and there is always something new in every problem which cannot possibly be predicted in advance. Rules have value in the experience which has produced them, or which can reproduce them. What is actually to be desired, rather than these pre-existent ideas, is a rich and fertile experience out of which will arise the appropriate materials for the solution of any problem.

But this last statement gives us the cue we desire for the definition of the content of the moral for education. If the good is relevant to the activity-situation, and the solution of the problem must rise out of experience itself, then the content of the good must be not a content of materials but a content of method of dealing with experience situations. Professor Dewey has said that that which gives moral quality to any situation is the necessity for asking the question: "What is the action that is demanded at this point?" and that which brings in the "good" is the asking, and satisfactory answering of these questions: "What are the conditions which demand action?" and, "What is the action that these conditions demand ?"

That is to say, the "good" is not in some specific act, or in some specific way of thinking, or in some precept or rule that is to be made to apply at this point. The good is in the actual grasp of the situation, taking into account all the conditions that are in question and all the elements that demand consideration, and all the values that are presented in consciousness; and in working out from these a completely unified end, which shall be criticized in terms of the means for its realization, and which will be, accordingly, related to the world of action. Cooley says: "The right is the rational in the large sense of the word. . . . The right is the result of the mind's full work in grappling with a problem." right is in mental integrity.

But when we have defined the good in terms of the method of experience

I Cooley, Human Nature and the Social Order. 
in attaining and maintaining its own integrity, we seem still to have neglected some factors. What of the relation of the individual and the social? of the place of impulse, and the distinction between the "carnal" and the "spiritual"? As to this latter question, the answer lies in the foregoing account, and in the description of the method by which the self rises in a constantly differentiating consciousness. The moral problem that this question raises is no longer the question of the higher over against the lower, of will over against impulse, of the moral over against the sensual, of the rational over against the irrational. It is wholly a question of the organization of these earlier, and less conscious and less definite phases of experience into the world of the will, of the moral, of the rational. It is thus that modern psychology and ethics have overcome the old dualism between the higher and the lower, and given unity, or the promise of unity, to the inner life of man. But the logic of this process will be treated more fully later.

As for the first problem noted above, the relation between the individual and the social, this method of regarding the problem is ready to answer that this old antithesis is no longer psychologically admissible.

The process of mental development may be defined indifferently from the social or individual side. Every act that defines individuality, defines the consciousness of others also. There are no "special powers" by which the individual takes up social values. . . . Everything that tends to individualize and define experience tends to socialize it also. The two developments are absolutely correlative. ${ }^{x}$

But, of course, this we have already seen to be the case in our discussion of the appearance of the self.

Social psychology is perfectly sure of its position, here. "The social and moral reality is that which lives in our imaginations, and affects our motives." "The immediate social reality is the personal idea. . . . . Society is a relation among personal ideas." ${ }_{2}$ "Society is simply the collective aspect of personal thoughts." "Society is rather a phase of life than a thing by itself . . . . it is life regarded from the point of view of personal intercourse."3 These are statements out of the most modern] doctrine. But much the same idea can be found at least as far back as Hegel, e. g., "The state finds in ethical custom its direct and unreflected existence, and its indirect and reflected existence in the self-consciousness of the individual." "The state .... is the realized substantive will

r King, Psychology of Child Development, p. r31.

2 Cooley, Human Nature and the Social Order.

3 Ibid. 
having its reality in the particular self-consciousness raised to the plane $<$ of the universal. . . . . The individual has his truth, real existence, and ethical status only in being a member of it."x

But if the objection still persists and the plea is made that the problem of ethics is, after all, the socialization of the individual; and that, therefore, the problem of moral education is to be stated in like terms, the answer is that this is just what our argument has led to, but with reference to more fundamental results than the mere socialization of the individual. For the individual must be not only socialized, he must become an individual, not merely repeating or copying the world's life, but creative of experiencevalues in his own right and person. If we turn to the most recent treatise on the subject of the moral life, ${ }^{2}$ we shall find that a constantly increasing stress is laid on the intelligence of the individual, and those deeper processes, the impulses and affections, out of which the intelligence rises, together with the growing demand for the transformation of customary into reflective morality (which surely illustrates the point of the preceding argument); and, on the other hand, there is a constantly growing emphasis upon the social nature, or rather the generalized nature of the objects and ends to which personal preferences are to be devoted. Or, as Hegel would ssay: "The universal is the concern of every particular person. Everything depends upon the law of reason being incorporated thoroughly with the law of particular freedom. My particular end thus becomes identical with the universal." And Kant had said even before this: "Act always from a principle fit for a universal law."

The contribution which modern ethical theory has made to these conceptions of Kant and Hegel is to be found in the modern idea of the moral as growing up out of, but organically connected with, all the other elements in the historical and psychological life. The purely instinctive in group or individual life becomes the customary, or the habitual; and this in turn becomes the personal, the intelligent, and the self-conscious. ${ }^{3}$ There is progress here, but no break of continuity, and no dualism. This makes the problem of moral education more simple and its solution much more possible.

Thus, we have seen that the ethical is the rational, the intelligent, the grasp of conditions and control from within, the conscious self that answers to the actual conditions in the world of action. The final demand of the moral life, and, accordingly, of moral education, is this: that the process

x Hegel, Philosophy of Right.

2 Dewey and Tufts, Ethics.

3 Ibid. 
of experience through the plastic years shall result in the complete organization of the processes of reflection so that the individual may be prepared to apply his experience at any point where moral tension may arise. All the contents of experience are moral as they minister to the felt needs of life. But not all contents are usable, for to too great a degree contents are taken on as so much good in themselves, or as future ministers of good, without submitting to the logic of constructive experience. Consciousness, intelligence, organization of the contents of experience to fit them to the uses of experience, and the organization of the reflective powers by means of this organization of the contents of experience-all these are bound up together in the processes of concrete experience, and are functions of the developing self. The fullest development of these is the aim of education, in general, but the particular interest of moral education.

One word more. Nothing has been said, in this section, about ideals, or purposes, or character, or the necessity that is supposed to underlie both education and morality. The foundation of this discussion has been the fundamental presupposition of activity-the necessity of action which inheres in experience itself, and without which there could be no experience. All life is experience, and all experience is educative: the necessity which underlies education is found in the question of the psychologist: "Why is experience always reaching out, persistently trying to define itself more and more adequately ?" and the answer is given in the words of the ethical philosopher:I "The moral necessity for education . . . . is the necessity' for knowledge to do what is trying to be done, the dependence of the uninformed impulse upon means, method, and interpretation."- Experience will and must go on: why should education not accept that fact and build upon it, helping impulse to find its ideas, the growing will its defined aim, and the rising self its freedom by means of a growing consciousness of values and of controls? Life evolves from within: why should not education work from within, develop from within? Is not the dawning experience promise of the full world of the future? Why should not education in all its phases become moral by aiming to secure to the developing experience the possibility of constructive and reconstructive organization by which, in its natural career, the ideals and purposes that it needs, the world in which to realize those ideals and purposes, the controls that will make it socially acceptable, and the self-consciousness that will make it socially inclusive and responsive, will all be developed?

To the more detailed logic of this process we must now turn. I908.

I Mead, "Philosophical Basis of Ethics," International Journal of Ethics, April, 


\section{THE LOGIC OF MORAL EDUCATION}

In a previous section a brief sketch of the character of experience in the modern world as distinguished from the more primitive forms of experience was given. A brief elaboration of that description is called for at this point. Traditional educational practice has naĩvely proceeded on the implicit, if not explicit, assumption that the world of the adult experience has objective existence-as much for the child as for the mature man; and the logic of that objective world has seemed to be that its existence lay in a mass of particulars, each with its possible appropriate "idea"; and education was just the process of acquiring those ideas, one by one"line upon line, precept upon precept, here a little and there a little." An unfortunate but rather natural misunderstanding of the Herbartian doctrine of apperception has helped to continue that logical error almost to the present, in education; and it has given the scientific foundation for the doctrine of "direct" instruction in morals.

Opposed to this lies the whole interpretation of experience from the point of view of functional psychology and instrumental logic. These sciences begin with the activity of experience as fundamental, and they point out how in the creative and re-creative processes of experience the world of objective reality is built up. This we have already seen to be the case: the social and the physical worlds are constructs of experience, arising in consciousness, evolving from within, and taking on the characters which the conditions of experience compel them to assume. Experience is fundamental, and creative, not merely secondary and acquisitive.

But experience has two general nodes: the instinctive or habitual and the attentive or reconstructive. In the primitive world instincts and habits mediate the whole content of experience, save, perhaps, that reconstruction which takes place in the period of adolescence and which is given such social significance by the ceremonials of many primitive groups. But the complexity of our modern world is constantly intruding upon the fixed forms of habit, and compelling the reconstructive processes of attention to function: this is the heart of modern world-creativeness, both on the side of the social contents and in terms of "things." Thus do society and the physical world slowly develop in the consciousness of the individual: not by the mere addition of atoms, particulars, facts; but by the creative differentiations within habits and objects that have, hitherto, functioned satisfactorily.

There are three specific levels of this logical development, corresponding to the three levels of development of the moral order of experience, noted above. Experience begins in instinctive and impulsive forms. 
These practically fulfil the description of Kant: they are "forms without content"; i. e., they are responses, modes of activity, inherited "categories" without definite or determined stimuli. (A few do have fixed stimuli from the first.) Corresponding to these "forms" the child manifests what Professor Dewey has called "direct attention," i. e., "attention" is focused wholly upon the outgoing activity: there is no discrimination of stimuli, in the conscious sense: only a sort of blind seeking for content to fill the forms that are ready to be filled. The child is absorbing the world. There is a sort of discrimination present, however; it is of the same sort which the chick displays when it rejects the orange-peel and swallows the egg-yolk, and, eventually, disregards the orange-peel altogether, though always accepting the other. This form of discrimination is the foundation of all the world-creative discriminations and reconstructions of the developing experience.

Instincts become "filled" with this discriminated content of the implicit environment: these filled instincts, or instincts with their stimuli determined, or instincts organized into the structure of the social and physical world, are habits. And here we have risen to the second level of development. But the child reaches this level only through the compulsion which appears in the struggles between instincts to get themselves established in the world of actual content. In those preconscious conflicts and reconstructions the tools are being forged with which the more complex conditions of experience are to be conquered. Sensation is present from the first, of course. But sensation slowly organizes itself into perception under the demand of the growing experience for a world of meaningful content. But the child must learn to perceive, as truly as he must learn to reason. A perception is a real content of meaning singled out of the "booming, buzzing confusion" of sensation. But perception involves memory, and the beginnings of judgment, and primitive forms of imagination, and the powers of abstraction and reflection. And so, with the appearance of this level of perception, we have the beginnings of the distinctively human period, the perceptual order, and the roots of that world-constructive consciousness in which the self, the social order, and the world of means will appear. Experience will now begin to take on the forms of "attitudes,". and the discriminated instincts will appear under the forms of "categories of the understanding."

On this second level, experience will be organized in the general forms of social habit, and the general relationships to the social order will be in terms of a customary morality; not, indeed, the mere custọmary morality of the primitive man-for the life of the child in the modern world is con- 
ditioned by forces which the primitive man did not know; so that the morality of the child in the years from three to ten will be that of his immediate society, conditioned by the implicit creativeness of his own reactions upon those forms: he feels the fact of social organization all about him, but he does not feel its meaning. Perhaps it could be said of the primitive man that in this customary or habitual stage-the mature stage of his experiencehe feels the meaning of social organization, but does not feel the fact.

The life of the child expresses itself in this period in the form of voluntary activities, in which attention is directed to the working-out of some practical end. The great word for this whole period is "practice." Regulations, theories, ideas, moral controls are all more or less unnatural, extra-experiential, and meaningless, and he seeks to keep out of their way, in so far as they are obtruded upon him from without. None the less, he welcomes ideas, theories, powers of control, that arise within the practical situations which he confronts and which justify themselves to him as a means for the extension or the control of experience to the ends that he seeks.

But the whole of his experience is social, i. e., it comes in terms of emotions and feelings, rather than in terms of ideas and complete controls. Reconstructions take place, of course, but these reconstructions possess him, rather than vice versa. Yet, of course, the slow processes of time are organizing the powers which will carry him into the distinctive characteristics of the next period.

In the next general period the child passes into the fulness of personality, of personal and intelligent morality, and into the expression of his life in terms of a reflective attention that is able to rise above the levels of feeling and emotion and to reconstruct the world as a complete and unified experience. The whole social order, including the personal self, has risen into consciousness, and has been differentiated from the world of physical things. The power to grasp the conditions of a problem, to carry the solution through all its various levels, and to actualize the self of the complete organization of the situation marks the level of logical and moral maturity, the completion of "education" in the preparatory sense, and the capacity of the individual for complete assumption of the responsibilities of membership in a moving society.

But it is to be noted that he is not merely an individual in the narrow sense of that term. He has developed in the midst of social situations, he has come into conflict with social institutions, and has been compelled to adjust himself continually to new phases of the life of society. He has found his growing, evolving self in and through his finding of these social 
conditions, and in the resistance which he has constantly felt in society he has been compelled to remake himself continually, constantly to "criticize his categories." The results are apparent. Every increment of the self has been correlative to an increment in the social order which is his creation of society. Society has become a correlative part of his unified world of action.

Corresponding to these three levels of logical development, and of moral control, we may note three levels in the "method of reflection," the complete organization of which was set down as the specific end of education. Experience grows through reconstructions in the presence of conflict-situations. Reflection comes, finally, to be the method of this reconstructive process, this power of adaptation. The foundations of reflection were pointed out in that primitive discrimination which the child shares with the chick. The mature development of this power lies implicitly in the organization of experience through the plastic years. In its complete organization we may note three levels.

The problem begins in the deep undercurrents of experience which lie far back in the predispositions, instincts, and habits of experience. This is still an obscure field-the particular province of genetic logic. But in some way currents of experience cross each other and inhibit the on-going activity. Inhibitions arouse emotions, and in terms of emotional presentations these conflicting currents of experience rise into consciousness. This is the second level. Here the struggle is between ends which clothe themselves in all the warmth of emotion and actually present themselves as "selves," possible future selves. An older ethical theory looked upon this situation as the final stage in the moral struggle, and demanded that choice should here be made of one or the other of these selves, as the only solution of the moral situation in moral terms. But to choose one of these selves, and to identify the present with that one only, is to ignore the values which give the other self power of appeal. Unless moral choice is to be made to include conscious and deliberate exclusion of genuine values, the only completely moral way to resolve the situation is to carry the whole conflict to a higher level (the third), and in the quiet of control which the reflective power gives, to organize all these values into a unified end which shall become the object of achievement, the self that is to be actualized. But reflection must do more than merely organize those values; it must organize them in terms of the means available for their realization. It must more clearly define the difference between the end in its relation to the more clearly defined social "kingdom of ends," and the world of mere means, the scientific phase of experience-the physical order. 
The power to rise to this level of insight and discrimination and to state the problematic in terms of a complete differentiation of its various levels of elements is both a logical and a moral power. The distinction between the two lies only in the fact that the moral has to do with the organization of the end, while the logical has to do with the organization of means to that end: but both are united in an organic whole. And that whole is the end which a completely moral education seeks.

But if objection be made that this is a purely formal end, lacking content and not emphasizing "character" and "ideals," the reply must again be made that such an end as this is realized only on the basis of the richness of personal experience which is the real content of life, and organization such as this is the very essence of that character which is able to "stand four-square to every wind that blows." And by giving vital meaning to the "idea"; by relating ideas to the initiatory impulses in organic fashion; by giving to the impulse this determinate outlet through ideas into a world of human meanings: by thus organizing the whole process of experience a real place is made in experience for that genuine ideal that "grows forever as we move." But especially does this way of looking at the whole matter do away with the fallacy of the existence of an objective world which needs to be acquired, and it gives to experience the quality which belongs in experience-personal creativeness. The moral world thus comes to possess the same reality as the physical world possesses; or even a greater reality, at least a prior reality, as being that for which the physical world is constructed-the end to which all else is means.

And education, whether from the logical or the moral point of view, becomes the ability to originate and apply constructively interpretative ideas at the point of action. Thus is life freed in all its elements; there is no need of external repression, for all the primitive forces have been organized into the control of the reflective processes, giving all the power which the primitive man possesses room, but subordinating it all in organic ways to the ntrol of the idea-producing capacity of experience itself. 


\section{THE LOGIC OF SCHOOL}

The foundations of all education are social. The child does not acquire a social consciousness or a consciousness of the social world. His first sense of self is called out by the presence of other selves. The whole process of education goes on in this social world. But consciousness grades down from the central region of clear and explicit meanings and controls to the fringe of uncertainties and the merest implications of meanings. Under the stress of life-conditions experience is constantly pushing back the boundaries of the clear and explicit and drawing within its central light the shadowy phases of the implicit: not in any arbitrary way, but as the actual needs of life require. Psychologically, this means the development of a more concrete self, and a more determined social and physical world in which that self may live; ethically, it means a richer store of experience with which to control the future conditions of experience, and a clearer consciousness of the complex elements that make up moral experience; logically, it means the growing organization of the reflective powers and the ability to carry through to ever-more-complete ends the processes of reconstruction in experience and of moral and physical world-creativeness. Educationally, it means the entrance into more and more of the "experience of the race," the "rich inheritance of the past," the "understanding of the present social order," or whatever other method of description befits the obvious fact.

Actually, the individual, child or man, lives in two worlds-the actual world of his own concrete experience, his own explicit world of moral and logical controls, represented by the general field of consciousness; and that implicit and unknown larger world of social and physical support and coercion, which lies dimly in the fringe of consciousness with its intimations of experience beyond the present, which rises into logical and moral meaning and objectivity in the reconstructive developments of experience, and which we may call the pedagogical world. To be sure, this pedagogical world is more or less of an abstraction, a "possibility of further experience"; but from the point of view of education it is a very real world. It is an abstraction in terms of the experience which has not yet come to include it.

We all feel the presence of this larger world, in some degree, today; we have the implicit sense of being "hustled" by forces that are beyond us. 
Experience contains elements that have not been rationally organized and brought under the control of our central life-purposes. These elements are an index of our worldwide life. Institutions are methods which experience originates for the purpose of keeping rational control over growing complications within experience. Experience seeks to attain, and to maintain, a unified development. The sense of being "hustled" is an indication that this unity has not been attained. Its logical purpose is to spur experience on to more strenuous efforts in the direction of attaining unity. But, when this feeling becomes overwhelming; when the instruments of organization seem to fail, and no new instruments are at hand, and the experience possesses no power to work out new instruments or methods -in any such case as this, experience is compelled to secure its unity by a definitely immoral method of excluding some of the elements of experience, even when those elements possess logical values. Thus is many a child shut out from the possibilities of participation in the world of ideas and ideal controls, by the overwhelming pressure of circumstance; and thus is many another child shut out from the participation in the realities of ideas, by the social pressure which destines him to the merely theoretical mastery of an existent world of theory, giving neither time nor stimulus to relate that world to practice. And to remedy these faults which are imposed upon the inner logical world of the individual by the outer pedagogical world, that outer pedagogical world-instead of reorganizing the logical instrumentalities, i. e., the institutions, by which to secure to that inner world a greater control over the processes of unified and inclusive world-constructiveness-seems to be content, in large measure, to temporize with the whole matter by attempting a sort of extrinsic "moral education" which, under the circumstances, can do little to heal the great organic wound that the experience of multitudes of individuals is receiving today. Thus have we returned to the point from which we set out.

What are those "logical instrumentalities" mentioned above as being the mediators of the larger world-experience to the developing experience of the child? They are, of course, innumerable. Compayré speaks of those which have not been institutionalized under the term, collaborateurs occultes, i. e., the innumerable forces of the world that play upon the life of the child, in implicit but very real ways. In general, we may say that these instrumentalities include every "influence that specializes the child's reactions and differentiates his world, and that at the same time increases his control over his own development." In the primitive world, none of these influences was specifically institutionalized, in its own right as related

I King, Psychology of Child Development. 
to the child, except, perhaps, the definite organization of adolescent awakenings into a means of emphasizing the content of the social life, and the reality and responsibility of the social purpose.

But when the primitive world of social habit was broken in upon by the growing complexity of social life, e. g., in Greece, these collaborateurs occultes could no longer perform the more complicated task of maintaining the organic relatedness of the child-world to the larger social world: there were phases of this larger education that could not be intrusted to the implicit educative influences of social life alone. We mark the slow beginnings of educational institutions of various sorts, which are not consciously established but which grow as the problem grows. Among these; and most important of them, is the school, in some one of its many genetic forms. Logically, therefore, the school is an instrument which experience has attempted to develop, pari passu with the development of the problem. The problem was as follows. The world of social experience, i. e., the pedagogical world of the child, was beginning its definite specialization and differentiation into the forms of practice and theory, habit and idea; practice went on as did habit in the older world; but practice needed theory for its illumination. Now, it is perfectly legitimate for such differentiation to take place, provided the two phases of it are constantly related back to the unity of experience-theory existing only for the illumination of practice, and practice looking constantly for the larger interpretation that theory can bring. So long, then, as the unity of experience is maintained, this differentiation of experience means the attainment of a larger content, a larger world, a more rich and varied selfhood, a more conscious control, and a larger organization of the powers of control, both logical and moral.

But institutions develop slowly, and, once incased in substantial social habit, they may resist all development influences, save those insidious ones which are at the heart of the Zeitgeist. And they may even sever all connection, save a purely formal one, with the fundamental influences which produced them. The school developed as an extension of the organizing powers of the home and general social influence, to help mediate the growing complexity of the world to the still simple experience of the child. At first its work was as immediately social as was the work of the home. Its foundations were in the implicit developments of the common social world. But the development of the social world, which determined the development of this extension of the educative instrumentalities of society, was in the direction of the theory of the social and physical worlds which grew up in the reconstructive processes of the times. The development of theory 
as a control in the reconstructive processes of society called forth the development of the school. All this was slow in its growth, but lasting in its effects. For, since the school grew out of theoretical needs, its mission was early conceived to be theoretical, rather than practical; or rather, since, and as long as, practice was provided for in the forms and activities that lay outside the school, the school was free to devote its energies to the theoretical aspects of the differentiation of experience; but always as these were determined out of the actual social foundations of life.

But as the world grew more and more complex, the school became more and more institutionalized, rationalized, and fixed in its forms and methods. Its social foundations were more or less forgotten: its curriculum became conventionalized without explicit reference to the social world in which it was to function; curricula were transplanted from one social situation to another without thought of relevancy or vital connectedness; and, especially, the whole work of the school came to be conceived of as the mediation of ideas from one generation to the next. This would not have been so disastrous had the logic of education been functional and genetic; but, of course, that was impossible. So the school has come down to us, changed in many important particulars, of course, and more and more yielding to change; with many of its older features reconstructed in conformity with the modern world-spirit, but in large measure still meriting the criticism with which this study began. The old foundations of social practice, which formerly gave vitality to the formal curriculum of the school, are practically gone, and the school is left suspended in the air, with its theoretical curriculum revealed in all its formal barrenness; but at the vital heart of it, struggling to pull itself back to earth by all sorts of means-commercial courses, trade courses, manual training, "fads" of many sorts, and last, but not least, efforts at "moral education."

It is evident that the institution of the school is no longer a type of that old organic instrument which at first mediated a growing world of theory to a growing world of practice in such a way that the result was a unified world of intelligent practice, or practical theory which was com. pletely at home in the world. The school has not widened and bruadened, as the limits of theory and practice have widened and broadened The school has not kept itself close to its proper roots in the immediate sucial life of the community. Too intent on "culture" and "liberal education," it has finally found that it is unable to give to the child either liberal culture or intelligent practice, save in the case of the extraordinary child, whom it cannot keep out of its rightful kingdom.

We have already seen that the school cannot be reconstructed as a sort 
of isolated model community, imitating the larger world in some of its phases; for it is certain that those partial results cannot be depended upon, either to be carried over into the larger world, themselves, or to become the bases of organic world-habits suited to the larger situation. We have noted also that in the city life of today the older foundations of concrete social practice, the home and the social neighborhood, with their work and their social criticism, are practically gone. Thus is the old and original gap widened immeasurably. The educational institution, instead of being called upon to mediate between the world of ideas and the world of concrete practice, is now called upon to mediate a world of ideas to children whose basis of practical experience is woefully meager and insufficient. The problem of the school seems to be, or seems destined to become, that of providing in kindergarten and grades the very fundamentals of social practice, and to organize into that practice the interpretative ideals which the practice calls for and develops, and to make the whole of this educative situation develop in the direction of some specific vocation which shall be both practical and theoretical - that is, technically mastered and intelligently practiced.

Such a school must, to be sure, be related to the actual present conditions and demands of social purpose and activity; it must be of the nature of the old apprenticeship schools, i. e., immediately subject to the pressures, coercion, support, and criticisms of the real social situation; yet it must be conceived broadly enough to make room for constructive development of the social and physical order of the world in experience, which has been described above as the real moral education. To this end, the real curriculum of the school must become, in the words of Professor Dutton, "the current of social activity that makes up the world." This social activity can be analyzed into its elements of practice and theory, and graded to the stages of the child's development; education will begin with practice, and by the successive enrichment of practice by means of ideas, and the actualizing of ideas in terms of practice, the actual modern world can be so constructed as to make possible, once more, the unity of experience; but now, under the leadership of intelligence.

Such an educative activity will begin just where the child is, and it will base itself upon the principle that all experience is educative, not merely the experience of some classic past. It will attempt to build upon the child's own consciousness by organizing more and more of experience into the objective forms of control. With some children this will not be a problem of organizing a "situation" in the first place; for many children seem to delight in working out the deeper implications of their imperfect 
experiences; with others it will take the form of getting the child into a situation which will be real and interesting and from which the child cannot escape without actually getting the values which arise from the living and developing of that situation. It is to be understood that the foundation of a moral life is actual content of experience: there should be no great haste to get to the "moral" training. All experiences which are concrete and vital will minister to the later moral life. Educational situations must be of this character, and all that can be brought in to help the child to comprehend the meanings of the experience, as relating it to nature and to human nature and to the social order, will help to make it more completely educative.

And especially must the heart of the whole school work be the effort on the part of the teacher to secure to the child a real control of the method of experience. This is a delicate matter. It is very easy to make the child oversophisticated. The child's attention must be kept upon the content of experience, but the teacher's efforts must be constantly directed toward making that implicit content organize itself into definite forms, categories, controls, method of experience. It cannot be doubted that most of that which is called bad in boys and girls comes from the lack of method of handling new experiences. In the complexities of modern life; in the life of the street and the school; in the overwhelming complications of the educational collaborateurs occultes which surround the child, new experiences are constantly being forced into attention: overstimulations and excitations which, in the lack of adequate powers of organization and control, can have but one result: the child finds new experiences pleasant, and goes after them.

Organization of control is slow, at first, for there must be large content out of which experience of control can arise. The child's world must be brought into the school, not some foreign world; or rather, the school, as an instrument of interpretation, of social control and criticism, of social support and compulsion, ought to be brought into the life of the child, organically at that point where the home begins to fail of performing these things completely. For the child's life and development must be interpreted to its growing consciousness, it must be controlled and criticized by forces that appeal to the child as resident in the actual world of living reality, it must be supported and compelled to activity by elements that justify themselves to the child as intrinsic and not extrinsic and extraneous. When the teacher and the curriculum and the social world of the school come to have these valid contents to the child, the isolation of the school will be a thing of the past. 
Education must begin with the child's native endowments; but it will begin by seeking to free as wide a variety of these as possible, for the richness and variety of the personal life of maturity will depend upon the richness and variety of these native activities which are brought into actual functioning. The first six or seven years of life will be spent in organizing these activities into the social and physical environment, filling them with the concrete content of the world as it comes to the developing experience of the child. It is, largely, in the richness and variety of this concrete content that the possibility of a later organization of life to moral ends is made possible. For, as before pointed out, consciousness, the larger sense of self, and the more complete organization of the reflective powers by which experience finds its complete control-these are all functions of those reconstructions which grow out of the conflicting conditions of experience. If life should embody but a single impulse or activity, it could never know more than this; its term would be spent in the service of this one aim. But a multitude of impulses and activities will be constantly conflicting and calling for reconstruction; and this will mean the possibility of the larger ends of education.

In the preadolescent years, after six or seven, the child is actually engaged in organizing these preliminary materials. Ideas will be in demand, but they must be ideas that are actually vital to the situation. Activities will be most dominant, and the idea must always be the servant of the activity. Can the school be organized in these years around these dominant activity-motives of the child? Professor James declares that the book ought not to predominate until at least the fifteenth or sixteenth year. ${ }^{\mathrm{I}}$ But what would our schools do under such a system? There is a whole primitive world of activity and impulse and constructiveness and social content that needs no book for its mediation: it needs activity, opportunity, stimulus, social support, social criticism, social compelling, social interpretation; but it needs freedom for the development of the organizing powers of the individual experience, it needs silence, and length of time; and it needs release from those whom Browning speaks of-"The fools who crowded youth, nor let me feel alone."

For the end of this period as it approaches the adolescent years with their profound emotional disturbances must see the child pretty definitely selfcentered, stolid, and mature. In this way, alone, will he be able to come through the tremendous cataclysms of the next period without complete destruction. Dudley Kidd says that the Kaffirs are completely demoral-

I Monal Instruction and Training in Schools (edited by Professor M. E. Sadler), Vol. I, p. 94. 
ized by the experiences of adolescence. From that time forth the whole of life centers in the experiences of sex. The white child escapes from these decentralizing results by reason of the fact that he has built up a core of organization and a premature maturity which can withstand the dissipating effects of the emotional disturbances of the storm and stress years. The school must organize itself into this fundamental phenomenon, and bend itself to this situation.

But in the adolescent period the child comes to the time when ideas are rising, when problems are appearing, when experience is overflowing. There is definite opening-out of the complete social world and a foundation is appearing for relating all experience to the whole human experience. There is a demand for something to tie to, some line of activity to realize oneself upon. There is a demand for outlet and for ideas for mediating that demand. This is, traditionally, the period of religious conversions. But children differ greatly in the characteristics of the period, save that all, either slowly or in great emotional transformations, make life over in this period. This is just a plain statement of fact, which the school must organize itself into. Conversion, or transformation, or growth ought to become definite forms of organizing the individual into the complete and mature order of the social world. Vocational interests and activities, social alliances, intellectual points of view, ideals of character and purpose, all are wrapped up in the way in which the educational forces bring their interpreting, supporting, compelling, and criticizing powers to bear upon this period. The youth will come out of it with a broad variety of genuine interests, and with a full social consciousness, and with powers of reflection becoming definitely organized into instruments of analysis and control, if only education can be made to organize itself so into the actual course of adolescent experience as to be able to give that experience the interpretation and support it needs, instead of standing outside that experience and attempting to dictate its course into conventional channels. Here is where the moral life as an evolution of the inner life in terms of personal creativeness will get its real enfranchisement-or its tendency to half-forms, to partial results and mere conventionality.

Now, no detailed pedagogy of such a school is possible, at present. That is the work of experimentation and trial which numerous laboratory schools are attempting to carry out. This organic conception of education lies already at the heart of what is called the "new education." There has been no effort in this study to prove that no such conception has existed in the past, or that the ideal of much present-day education is not just this. The whole purpose of this study has been to show that all the tre- 
mendous efforts in the direction of "moral education" must relate themselves back to this fundamentally organic point of departure, and that the demand for moral values in education must realize itself in terms of functions of the social life-consciousness and organization of control, power of analysis and of reaching a unified plan of action, power of presentation of all the concrete elements in any "moral situation," and the method of experience which can deal conclusively with the problems of life. These things are not "natural," in the sense that they can be depended upon to develop under any and all circumstances; they are not to be grafted into experience in terms of ideas and extrinsic ideals; talks on moral habits will not produce them beyond possibility of failure; isolated forms of corporate imitation of society will not be sufficient; life itself cannot be depended upon to do the work; the home has long since lost its power to carry the process through; the public school, as at present organized, is too remote from the actual realities of life and action to make its appeal in other than intellectual terms.

The thinking that has wrought out the modern world of mature problems and activities, that, on the great frontier of human endeavor, is solving problems of individual and social well-being, and building deeper into the world of theory with every day we live, must turn its constructive thinking, also, upon this problem of assuring to the youth content of experi-t ence in terms of a consciousness of self and the world, and organization of 1 experience in terms of the complete method of reflective analysis and synthesis, by means of which the living and vital problems of the present shall become the heritage of the completely educated individual. Not for the few to carry on, merely; but for the whole body of men to share, each according to his powers doing the task that socially needs to be donethis is the burden of democracy. It is the meaning of moral education.

Social psychology gives us the general character of the educative process-the development of the selves of social relationships, and the world of social means. Ethical theory gives us the content of moral education, or complete education - the social consciousness that is able to rise to the demands of a situation requiring action, and so to organize that action as to realize all the values that are involved in it. The logic of experience gives us the method of realizing such a complete organization of the powers of control within experience. Of course, such a method must here be stated in general terms; in any particular situation it will be necessary to make it keep close to the details of particularity. Character, the end of moral education, is to be defined as such an organization of personal selfhood, by means of large and rich content of experience and a correlative develop- 
ment of the powers of reflection, as shall insure that that self will, in successive stages of its development, successively identify itself with the "highest when it sees it"; but in that very identification it will be gaining the power to rise above the old good to new levels of good as the conditions of life demand.

Can the school ever get back into the life, in this organic way, and relate itself to the actual world of the child, and become the means of organizing the implicit environment of the child in such ways that all these results shall be attained: the ever-more-inclusive self shall be called out, the more explicit consciousness shall be gained, the more complete content of materials for organization shall be secured, and the definite process of organization shall be carried forward? The answer to this question is a problem in social pedagogy; but the answer to it is essential to a final solution of the problem of moral education. So moral education merges even on its formal side over into the larger question of social pedagogy. It is certain that many of the ideals of the advocates of "moral education" today are impracticable; for there is little use in filling a boy with "moral ideals," most, or all, of which he must lose in the actual work of the world. Moral education must not come at the problem from that extrinsic point of view. The life of the growing child is a function of the life of the social whole. To make him officiously "moral" is to make a fanatic of him. His morality must be a power of control of experience within the experience itselfa power of control which is based on rich content of experience, and power to organize that content into interpretation at need. This is the real work of the school, or of the educative forces of the community. But it will take definite work along the line of social pedagogy so to instil this organic concept of education into the social consciousness and conscience that society will consent to see the school be made the vital instrument for this living education.

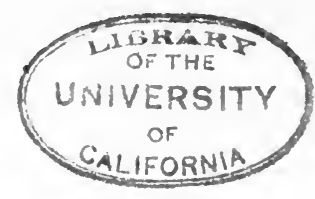





\section{UNIVERSITY OF CALIFORNIA LIBRARY BERKELEY}

Return to desk from which borrowed.

This book is DUE on the last date stamped below.

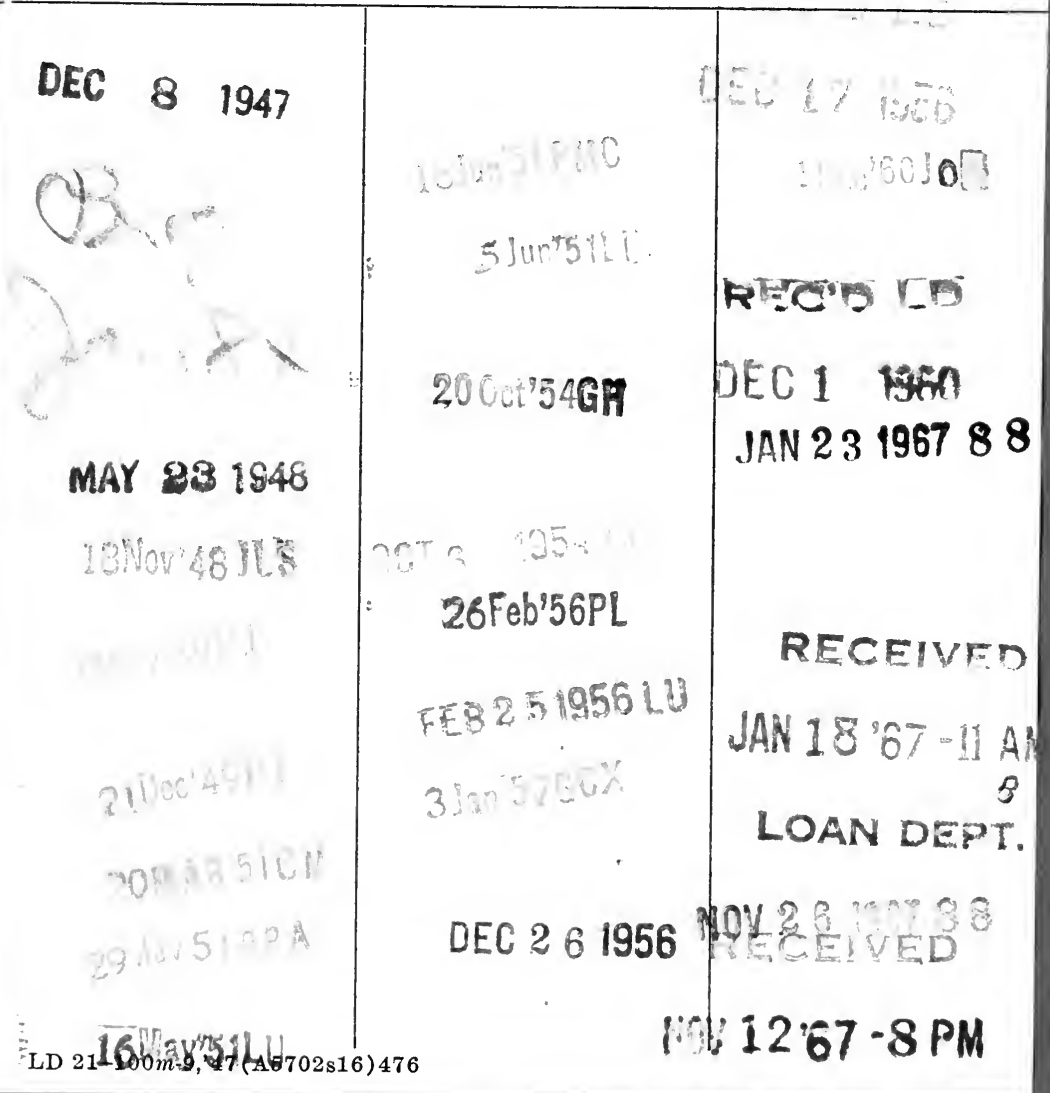




$$
20+464
$$

URATUSTY

CELITCS

$$
\text { LC. } 268
$$

$H=$ 
